\title{
INVESTIGATION OF THE EFFECT OF THE DECK MATERIAL ON THE COST IN CABLE-STAYED BRIDGES WITH DIFFERENT SPANS
}

\author{
Ali KÖKEN, Konya Technical University, Engineering and Natural Sciences Faculty, Civil \\ Engineering Department, Konya Turkey, akoken@ktun.edu.tr \\ Ahmed Ali Abdulqader FARHAD, Kirkuk University, engineering faculty, Civil engineering \\ Department, Kirkuk Iraq, ahmedibnali14@yahoo.com
}

\begin{abstract}
Recent developments in the social sphere also cause an increase in transportation activities. Increased transport activities lead to the construction of new roads and bridges. Different bridge construction systems are available to overcome large span obstacles. Cablestayed bridges are more advantageous construction systems than other bridge type building carrier systems in overcoming large spans through suspension cables. Therefore, it is also widely preferred by designers. The biggest factor in the development of cable-stayed bridges is undoubtedly steel cables. Cable-stayed bridges are bridge structures that become lighter with the increase of the span, which has a more expanded flexibility, and that includes a cable system with the effect of nonlinear factors. Costs of cable-stayed bridges vary according to different spans. The span as well as the deck material used in the bridge system have a great effect on the cost. In cable-stayed bridge systems, decks are constructed of reinforced concrete and steel.

The costs of cable-stayed bridges are widely discussed around the world; therefore, the effect of the span and deck material on the cost of cable-stayed bridges is being investigated. The main bearing elements of such bridges are cables, decks, and towers, and among these elements, the tower bridge carries all the weight of the bridge, even other external loads such as vehicle, wind, etc. In this study, the three-dimensional model of the cable, deck and tower elements that make up the cable-stayed bridge system was created and analysed using the CSI Bridge Program. The AASHTO LRFD Standards, which are widely used in the analysis of bridge systems with the CSI Bridge program and the design of bridge systems in the world, were used. In the study, the analysis and designs of cable-stayed bridges with reinforced concrete and steel deck at 250, 500, 750, 1000, 1500, 2000 meters span were carried out. The amount of materials and costs used in the analysis and design of the cable-stayed bridge systems were obtained and the results were interpreted.
\end{abstract}

Keywords: Cable-stayed Bridge, Bridge, Bridge Cost, Bridge Elements, AASHTO LRFD, CSI Bridge program. 


\section{INTRODUCTION}

There is an effort to move forward from the beginning of humanity's existence until today. With the developing social life, transportation activities are also constantly increasing. Wider and more comfortable roads are being built to meet the increasing transportation needs. Moreover, for this purpose, different types of bridge systems have been developed to overcome obstacles with a wide span. Bridge structures, which seem easy at first, have become more complex over time due to the increase in the spans to be crossed and the presence of multiple spans by adding columns. The complexity and size of the structure have highlighted the social importance of the building. Thus, bridges have come to the fore not only as structural but also as social objects [1].

As countries and societies develop, transportation becomes more important, and accordingly, the need for transportation structures (bridges, viaducts, etc.) increases and these structures become prestige structures. One of these prestige structures built in developed and developing countries is the large span cablestayed bridges [2]. The type of bridge where one or more towers support the deck through cables and where the cables are directly connected to the towers by a deck is called a cable-stayed bridge [3].

Cable-stayed bridges have been preferred around the world in recent years to cross medium and long spans due to their superior load carrying capacity, low cost, aesthetic appearance, and short construction periods [3] [4]. While the first cable-stayed bridges were generally built in non-seismic regions, in recent years, with the help of the developments in engineering and construction technologies, such large span cable-stayed bridges are also built in highly seismic regions [2] [3]. The cable-stayed bridge is a type of bridge that has been used frequently since the 19th century. The cable-stayed bridges are systems consisting of deck, tower and cable elements. While they were preferred for medium spans until recently, they have developed rapidly in the last two decades and have become applicable for bridges up to $1.088 \mathrm{~m}$ central span, such as Sutong Bridge. They can be designed as reinforced concrete, steel or reinforced concrete-steel composite [3] [5]. With the help of developments in engineering and construction technologies, cable-stayed bridges can be easily built in large spans [2]

The bent cable suspension bridge consists of the cable carrying the main load and the hanging deck. Since the cable elements are volatile, rigidity elements are also used to stiffen the bridge. The required additional rigidity is usually provided by utilizing the bridge deck. The most important problem in cable-stayed bridges is to eliminate swaying. Since this swaying cannot be completely 
ROMANIAN JOURNAL

removed, remedies for reducing it to the smallest possible level have always been sought. Today, thanks to the developing technological possibilities, rigidity is provided by using bridge decks. To reduce the effects of wind, the bridge crosssection is formed aerodynamically [6]. In cable-stayed bridges, the loads on the deck and the deck are carried by the cables. Tensile force occurs in cables due to these loads. The tensile force generated is transferred to the towers as a pressure force and towers transfer the pressure force to the ground. These tensile forces in the cables also create high-pressure forces in the deck. [2]. Figure 1 shows the load transfer scheme in a symmetrical cable-stayed bridge. The main features and the structural behavior of cable-stayed bridges are thoroughly explained in several references [8-12].

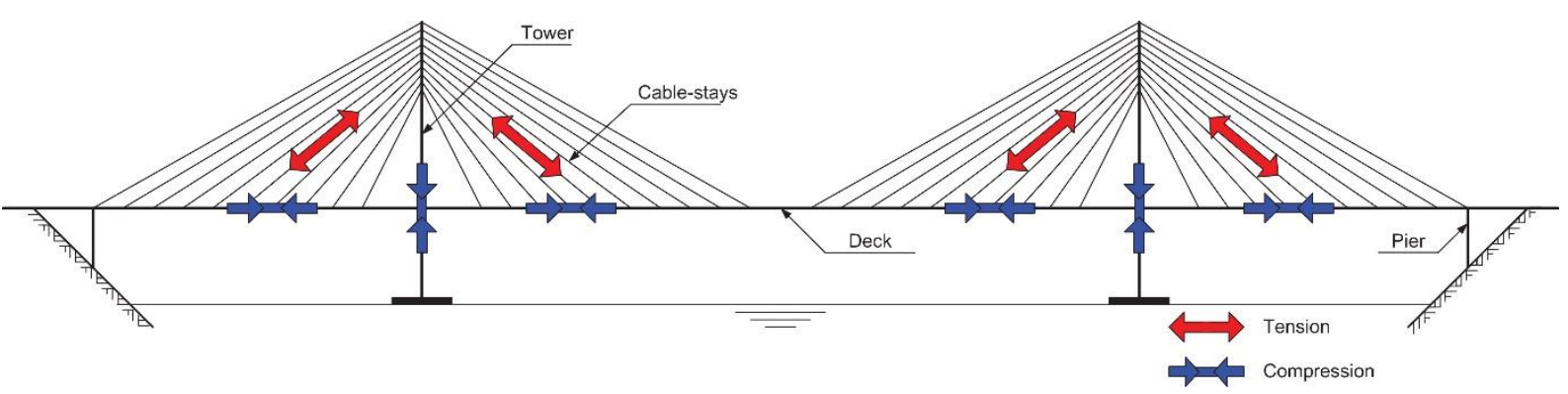

Figure 1. Scheme of load transfer in a cable-stayed bridge

Since cable-stayed bridges have structure carrying properties through cables, they are preferred by designers because they have superior construction technique compared to other bridge type structure carrier systems in overcoming large spans. The biggest factor in the development of cable-stayed bridges is undoubtedly steel cables. Cable-stayed bridges are bridge structures that become lighter with the increase of the span, which has a more expanded flexibility, and that includes a cable system with the effect of strong nonlinear factors. Costs of cable-stayed bridges also vary according to different spans. The span as well as the deck material used in the bridge system have a great effect on the cost. In cable-stayed bridge systems, the deck system is constructed as reinforced concrete and steel.

Thanks to cable-stayed bridges, multi-span distances can be passed easily, and in addition to their structural efficiency, these bridges give good results in terms of aesthetics. Nowadays, cable bridges are applied in large spans more economically and aesthetically. The general form of cable bridges is given simply in Figure 2. Cable-stayed bridges generally have two carrier towers and cables connecting the decks to the towers [3]. 
ROMANIAN JOURNAL

OF TRANSPORT INFRASTRUCTURE

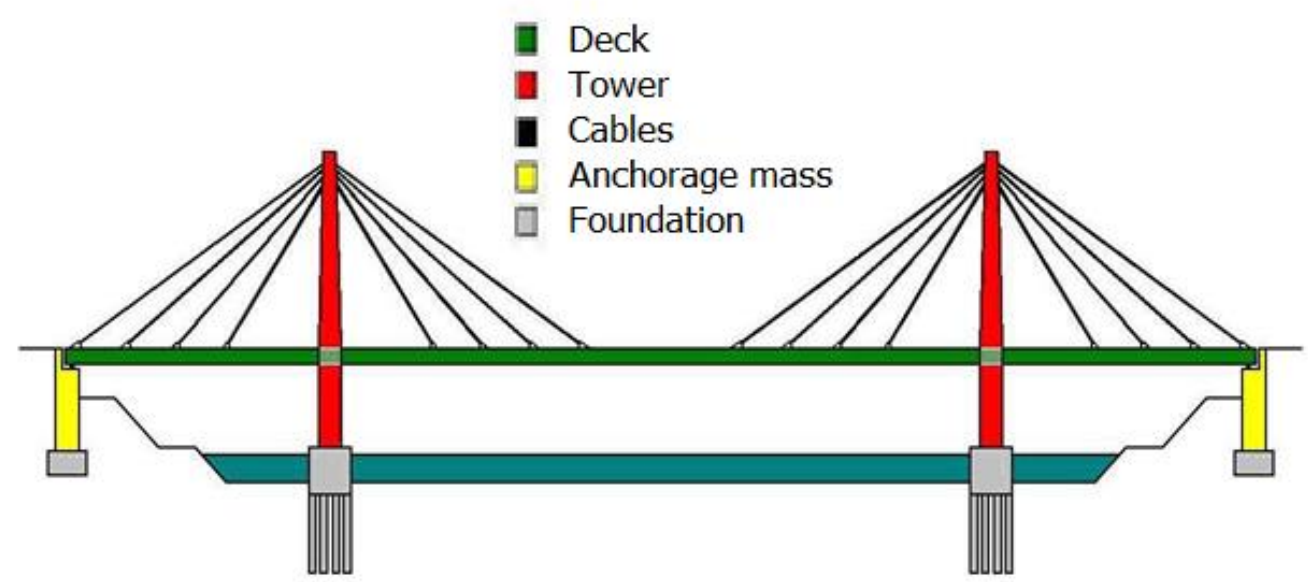

Figure 2. General shape of cable-stayed bridges [3]

When building cable-stayed bridges, tower systems are built first. After the tower is built, the main cable is pulled with the help of a crane and starting from both sides of the tower, the deck is assembled in equal numbers from the middle of the span [13].

\section{MATERIALS AND METHOD}

In this study, analysis and design were carried out with the CSI Bridge program to investigate the effect of the deck material and span on the cost of cable-designed bridges, which are widely used for crossing large spans [14]. The AASHTO LRFD Standards, which are widely used in bridge design in the world, were used in the analysis and design of cable-stayed bridge systems [15]. The bridge spans discussed in the study are as follows:
a. 250 meters
b. 500 meters
c. 750 meters
d. 1,000 meters
e. 1,500 meters
f. 2,000 meters

In selecting the bridge spans, the reason for choosing 250 meters as the smallest span and 2000 meters as the largest span, which is rarely used in practice, is the interpretation of the results obtained and the comparison with other spans.

The deck type of the bridge considered in the study is as follows:

a. Concrete Deck 
b. Steel Deck

According to the parameters discussed, cable-stayed bridge systems with reinforced concrete decks are named as ASK250-BE, and cable-stayed bridge systems with steel decks are named as ASKCE250. The abbreviations refer to: ASK: Cable-stayed bridge system

250: bridge span in meters

BE: Concrete deck bridge system

CE: steel decked bridge system.

\subsection{Cable-Stayed Bridges}

Bridges are one of the most important engineering structures that have made human life easier since their existence. Since ancient times, bridges have brought people together by enabling the crossing of streams, deep valleys, even continents. While the bridges built in ancient times were made of masonry and wooden materials with narrow, small spans capable of carrying light loads, today, these bridges have been replaced by reinforced concrete and steel bridges. For this purpose, reinforced concrete and steel bridges with large spans that can carry heavy loads are being built today.

Cable-stayed bridges are more economical engineering structures than their counterparts in terms of both passing large spans and using the areas under the bridges easily. Cable-stayed bridges are also important constructions in terms of engineering. Considering the high construction costs of such bridges and their logistical importance in their regions, it becomes necessary that the structural behavior of such engineering structures be determined very well. This is because damage to such bridges means the loss of life and property as well as the destruction of intercity transportation links [16].

\subsubsection{Basic Features of Cable-stayed Bridges}

Cable-stayed bridges are non-linear systems supported elastically by cables from the points where they are connected to the deck, and they are threedimensional systems consisting of cables that function on pressure from the deck and pull from towers [3].

The basic structural characteristic of cable-stayed bridge systems is the functioning of the deck as a whole with the pre-stressed or post-tensioned cables extending from the tops of the towers. Taking the horizontal pressure forces coming from the cables trying to pull by the decks provides an important economy in the infrastructure. The towers and decks of cable-stayed bridges being subjected to inclining together with large axial pressure forces caused by cables 
are the distinguishing features of cable-stayed bridges [3]. A typical example of a cable-stayed bridge is given in Figure 3.

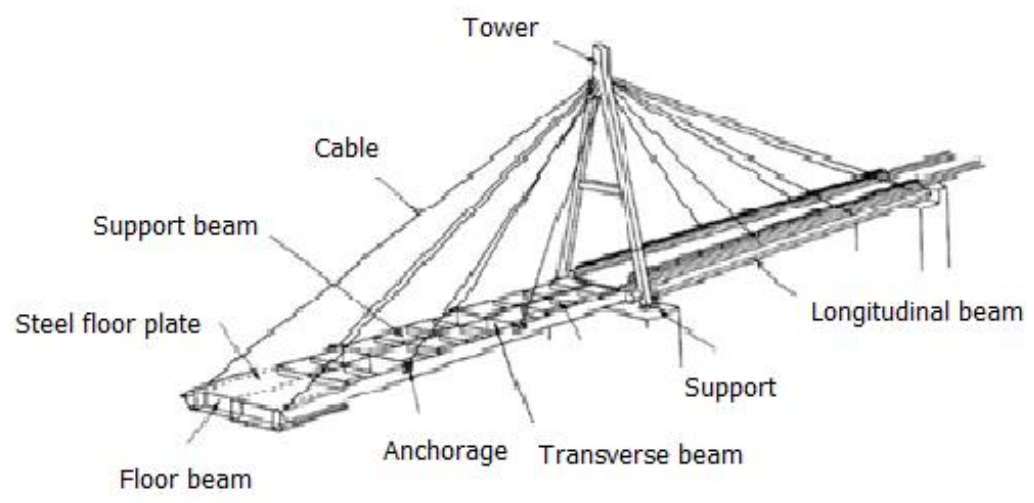

Figure 3. A typical cable-stayed bridge [3]

\subsubsection{Elements of Cable-Stayed Bridges}

Cable-stayed bridges consist of main elements such as tower, cable and deck. When the foundations that support the towers need to be made in water, they gain importance because they are expensive and difficult. Therefore, largespan cable-stayed bridge construction is avoided unless it is necessary. Cables are basic load-carrying elements and are attached to towers and main decks. The connection of cables to decks, towers and infrastructure is extremely important. The cable connections must ensure the full transfer of loads and must be protected against climatic conditions.

\subsubsection{Towers}

The towers of cable-stayed bridges are concrete structures built higher than the deck surface. The concrete used in the construction of the towers has highpressure resistance and low tensile stress. Due to the operating mechanism of the system, tensile force occurs in cable-stayed bridges, and cables transfer the tensile force to the tower. This tensile force creates a pressure force on the tower. Towers are elements that countervail this pressure, the bending moment, and additional horizontal forces caused by earthquakes and wind. Towers act as a part of the cable system. The buckling effect due to the high-pressure in the tower is critical. However, to prevent the towers from falling over, attention is paid to ensure that the horizontal components of the tensile forces are equal. The pillars that make up the towers are box-sectioned and are generally hollow. There are elevators in the towers to reach the road level and support saddles for maintenance and repair. 
Each tower consists of one or two pillars, and these pillars are interconnected by horizontal or diagonal beams [7] [16].

\subsubsection{Cables}

The most basic feature that distinguishes cable-stayed bridges from other traditional bridges is that cables form a part of the carrier system. In cable-stayed bridges, cables are connected to the deck and towers at a certain angle. Cables are the most important elements of such bridges that show nonlinear behavior. The free geometry changes due to the axial tensile force on the cables. This situation causes the stiffness to be affected, the cables are subjected to a pre-tensile force before being connected to the deck point, and in this case, they are connected to the deck. This initial tensile force is an important factor affecting cable behavior [2] [3].

\subsubsection{Decks}

The deck is the longitudinal bridge element that spreads and carries mobile vehicle loads. The carrier system of the deck to be used by the vehicles is generally designed as a closed box section. Generally, the cable connections of the deck are made from the connection points of the elements with the deck. For this reason, the problem of cracks has been eliminated by enlarging the cross-sections of the elements corresponding to these points or by taking the cable deck anchorage points into steel tubes and filling them with epoxy. Concrete or steel decks can be widely used in cable-stayed bridges. [17].

\subsection{AASHTO LRFD Standards}

AASHTO-LRFD standards allow bridges to be designed with force-based linear methods for certain bridges, taking into account the non-linear, inelastic behavior of bridges in terms of material. This standard came into force in the United States to replace the AASHTO regulation. The current AASHTO regulation adopts the design according to the load factor design (LFD), while AASHTO-LRFD adopts the load and resistance factor design (LRFD). When these two regulations are compared, according to the bridge spans varying in the LRFD regulation, a safe design can be made varying between 3.2 and 4 times, and in AASHTO regulation, safe designs can be made varying between 1.5 and 4.5 times [18].

\subsection{Computer Model of the Bridge}

The computer model of the bridge/construction was made using the CSI Bridge program. The bridge carrier system was modeled in 3 dimensions as cable, 


\section{ROMANIAN JOURNAL \\ OF TRANSPORT INFRASTRUCTURE}

Ali KÖKEN, Ahmed Ali Abdulqader FARHAD

Investigation of the effect of the deck material on the cost in cable-stayed bridges with different spans

deck and tower, and evaluated by making a solution under vertical loads, wind and earthquake loads. The live load module of the CSI Bridge program is used in the truckload descriptions on the deck. The program calculates the weight and mass of the carrier elements automatically. The weights and masses of non-carrier elements (Asphalt, guardrail, etc.) were entered separately in the prepared model.

\subsubsection{Modelling bridges with the CSI bridge Program}

In order to define the section properties for the frame elements in the CSI bridge program, as in Figure 4, material and cross section properties are defined from the window seen in Figure 5.

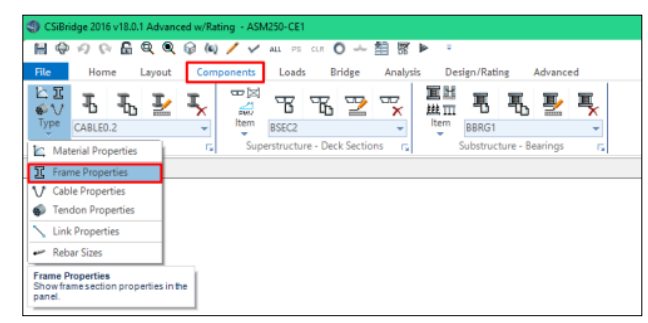

Selection of frame section

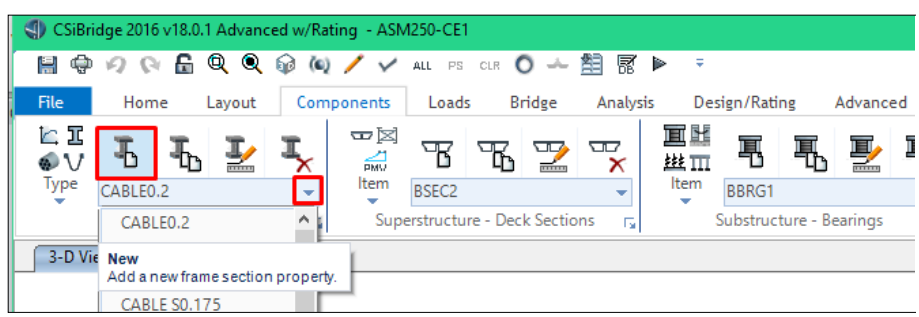

Adding new frame section

Figure 4. Defining of frame members

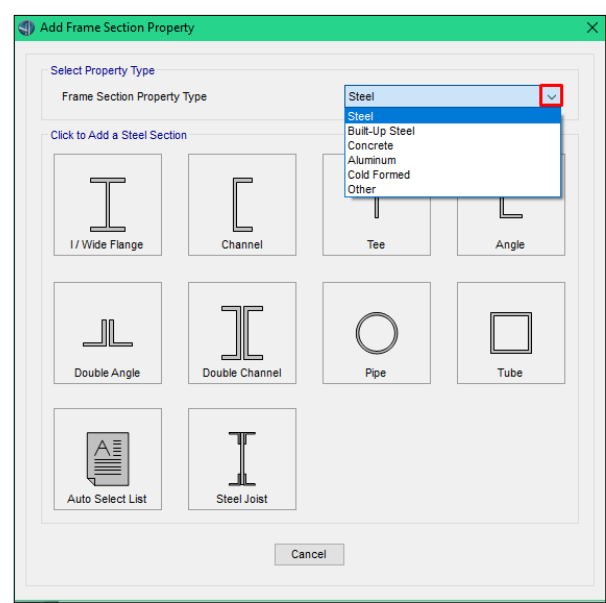

Figure 5. Defining of frame members and material properties

The process of defining the sectional properties of the deck was carried out as in Figure 6. Material and cross section properties are defined from the window seen in Figure 7. 
ROMANIAN JOURNAL

OF TRANSPORT INFRASTRUCTURE

Ali KÖKEN, Ahmed Ali Abdulqader FARHAD

Investigation of the effect of the deck material on the cost in cable-stayed bridges with different spans

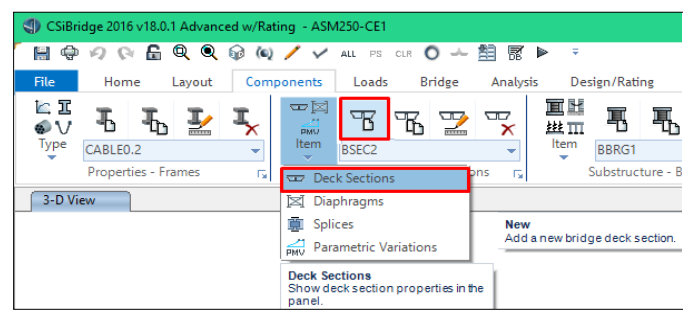

Selection of deck section

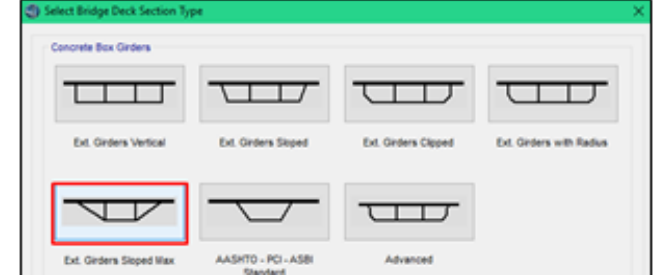

Selection of deck type

Figure 6. Defining of deck members

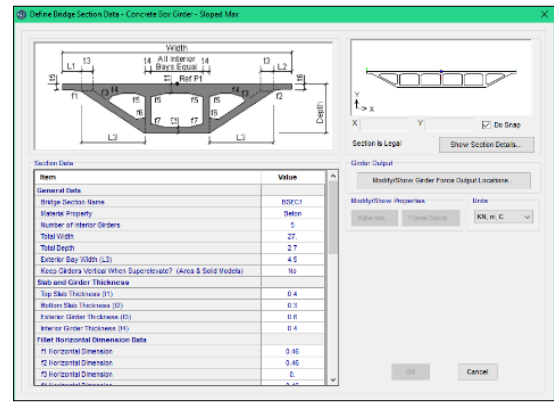

Figure 7. Defining of properties of deck

Figure 8 shows the picture of the steel deck and reinforced concrete deck systems used in this study.

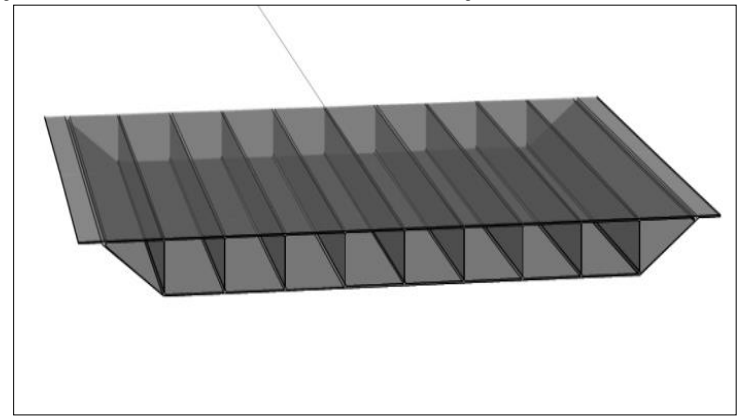

(a) Steel deck

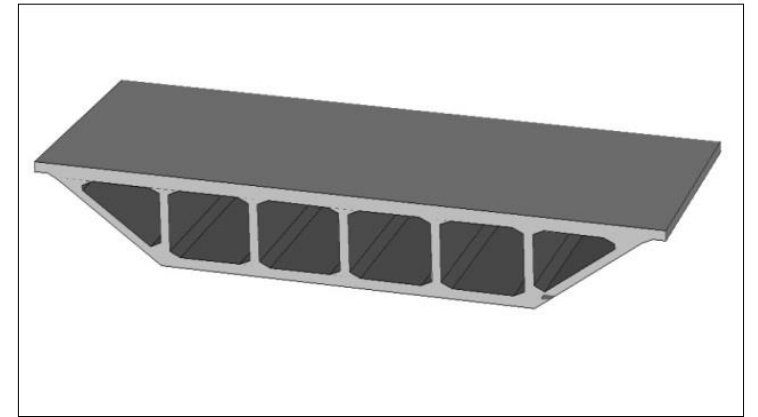

(b) Concrete deck

Figure 8. Computer model of decks used in this study

Finally, the bridge towers were selected as fixed support as shown in Figure 9 and the modeling process was completed. 
ROMANIAN JOURNAL

OF TRANSPORT INFRASTRUCTURE

Ali KÖKEN, Ahmed Ali Abdulqader FARHAD

Investigation of the effect of the deck material on the cost in cable-stayed bridges with different spans

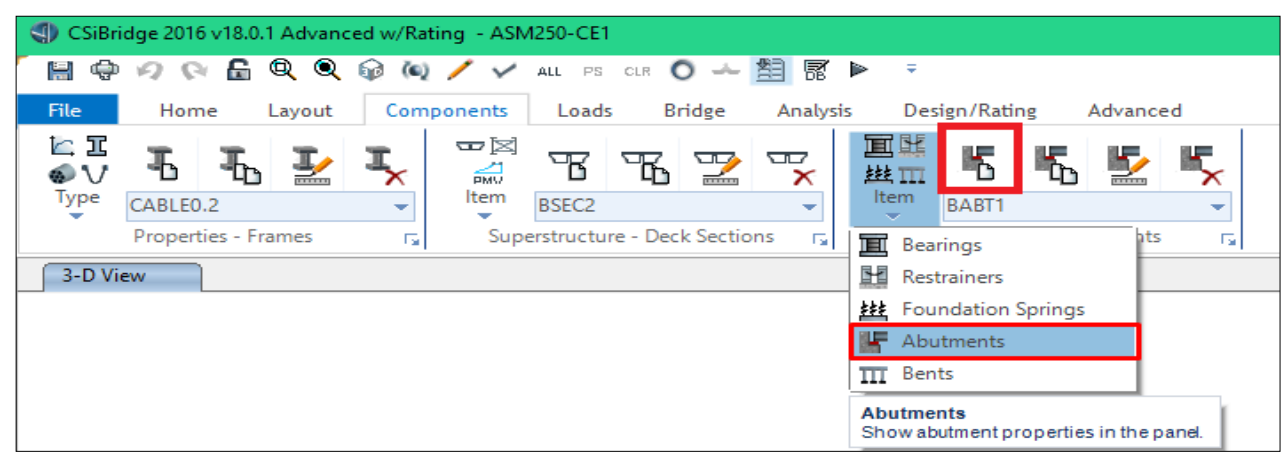

Figure 9. Modelling of tower

Concrete, reinforcement steel, profile steel and cable materials used in the construction of the bridges and their entry into the program were done as in Figure 10.

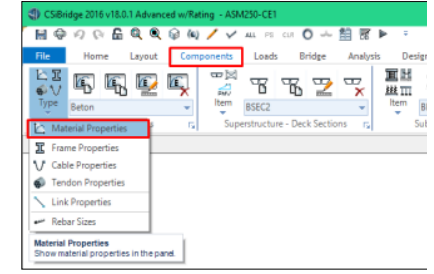

Selection of

material properties

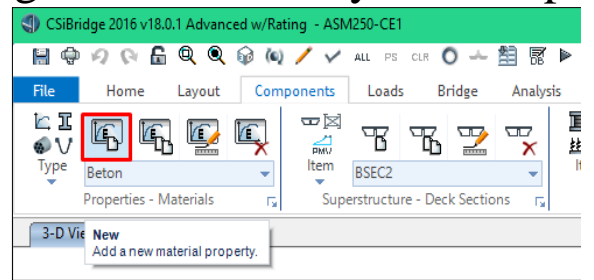

Adding new material

Figure 10. Entering material properties into the program

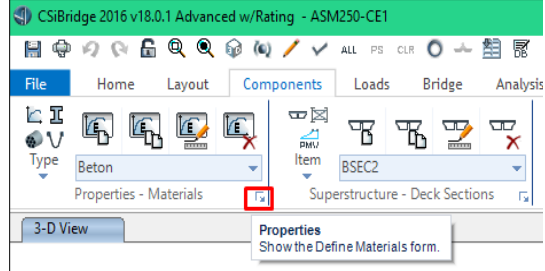

Adding material properties

All material properties defined in this study are given separately as follows:

\subsubsection{Concrete}

Concrete properties used in bridge construction have been entered in the CSI bridge program as shown in Figure 11. C50 concrete with a cylinder compressive strength of $\mathrm{Fc}=50 \mathrm{Mpa}$ is used in all bridge types.

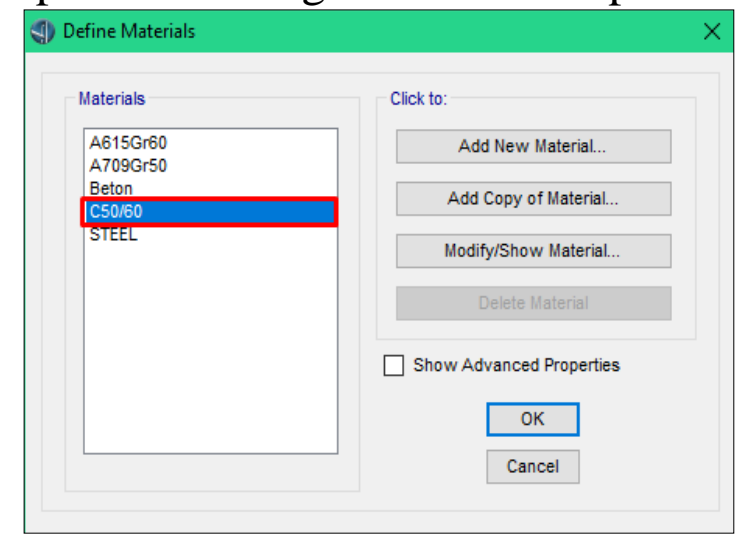

Define of concrete material

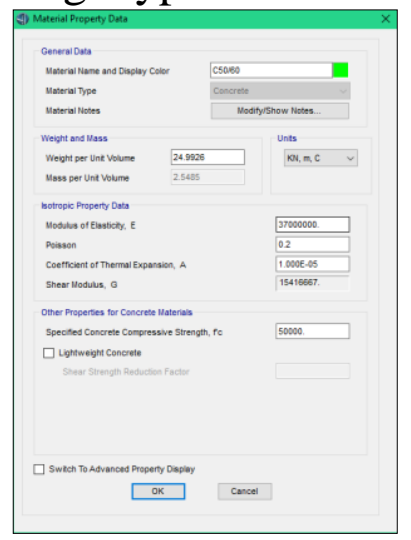

Properties of concrete

Figure 11. Entering concrete properties into the program 
ROMANIAN JOURNAL

OF TRANSPORT INFRASTRUCTURE

\subsubsection{Reinforcement steel}

The reinforcement steel material properties are selected as A615Gr60, which is defined as ready by the CSI Bridge program (Figure 12). A615Gr60 steel grade has a yield strength $\mathrm{Fy}=413.7 \mathrm{Mpa}$ and ultimate strength $\mathrm{Fu}=620.5$ Mpa.

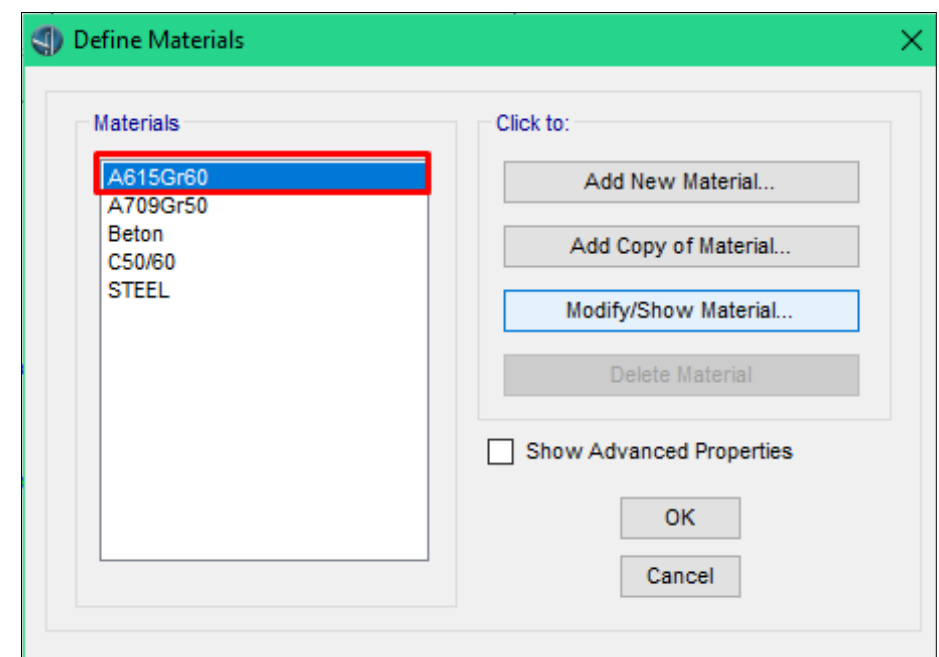

Define of reinforcement steel material

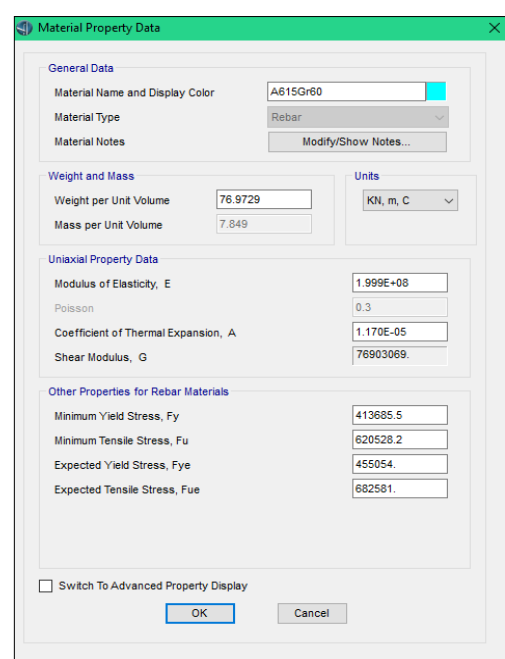

Properties of reinforcement steel

Figure 12. Entering reinforcement steel properties into the program

\subsubsection{Profile steel}

The profile steel material properties are selected as A709Gr50, which is defined as ready by the CSI Bridge program (Figure 13). A709Gr50 steel grade has a yield strength $\mathrm{Fy}=344.7 \mathrm{Mpa}$ and ultimate strength $\mathrm{Fu}=448.2 \mathrm{Mpa}$.

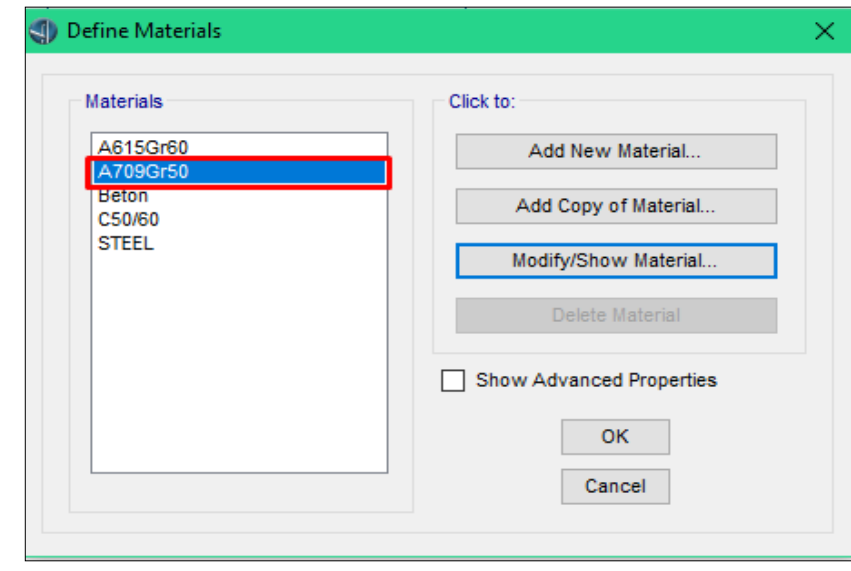

Define of profile steel material

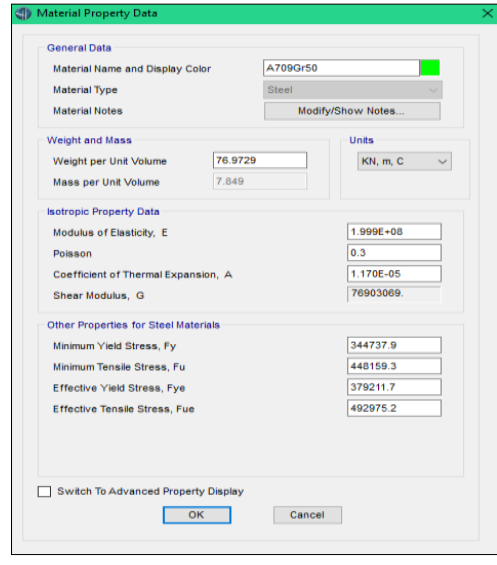

Properties of profile steel

Figure 13. Entering profile steel properties into the program 


\subsubsection{Cable steel}

Cable steel properties used in bridge construction have been entered in the CSI bridge program as shown in Figure 14. Cable steel has a yield strength Fy $=$ $1690 \mathrm{Mpa}$ and ultimate strength $\mathrm{Fu}=1862 \mathrm{Mpa}$.

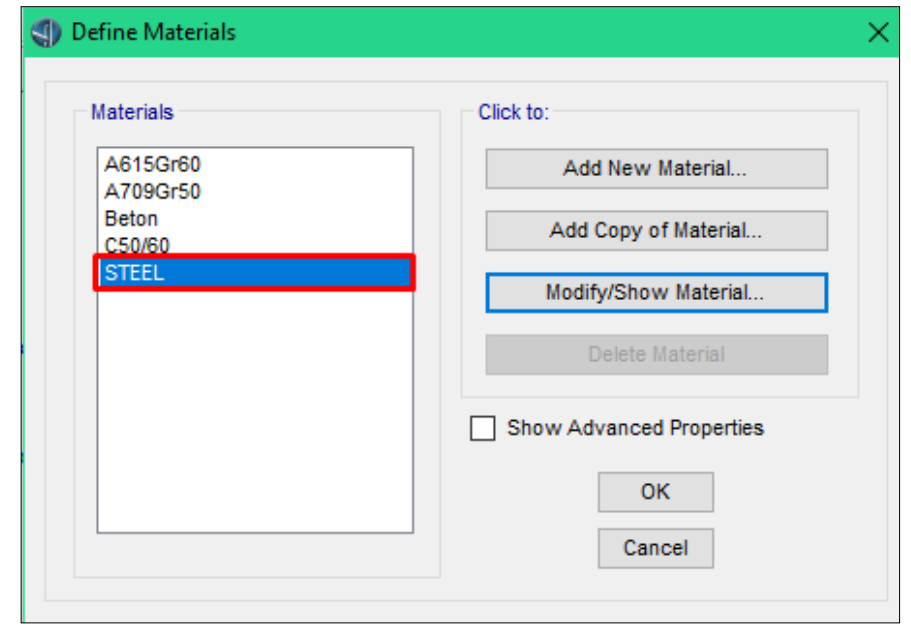

Define of Cable steel material

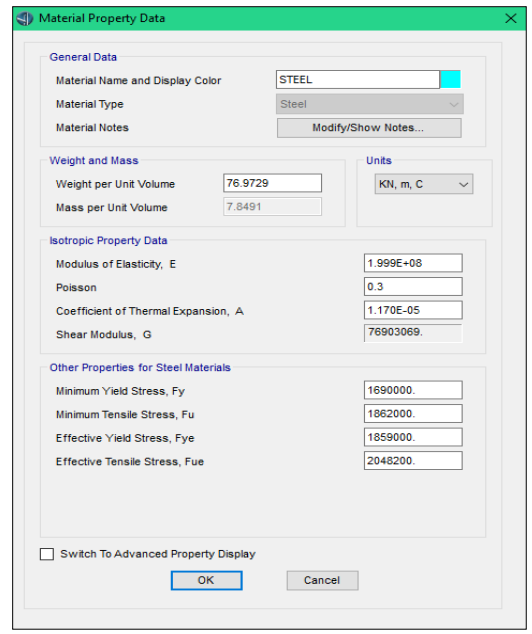

Properties of cable steel

Figure 14. Entering cable steel properties into the program

\subsubsection{Modeling and entering loads}

Loads acting on bridges: self-weight of the carrier elements, self-loads, live loads, wind load, temperature change, earthquake load and other loads on the bridge. The loads to be considered in the bridge design were applied to the bridges modeled by using the program's ready-made menus in accordance with AASHTO LRFD specification.

The computer model used in the solution of the concrete deck cable-stayed bridge is shown in Figure 15 [18]. 


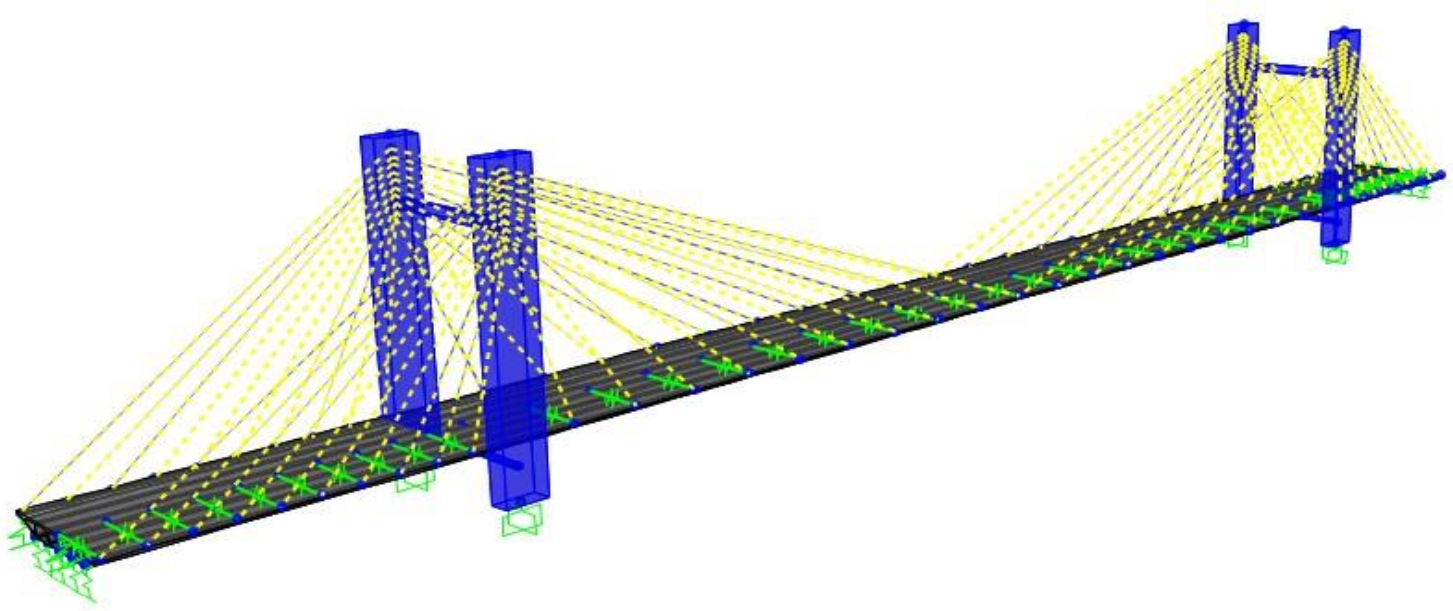

Figure 15. Computer model of the bridge

\subsubsection{Analysis and design of the bridge modeled with the CSI program}

After the bridge systems have been modeled in the CSI Bridge program, their analyzes are carried out. After analysis, internal forces and displacement diagram can be obtained as a result. As an example, the internal force diagrams obtained for the tower on a 250-meter span bridge are given in Figure 16.

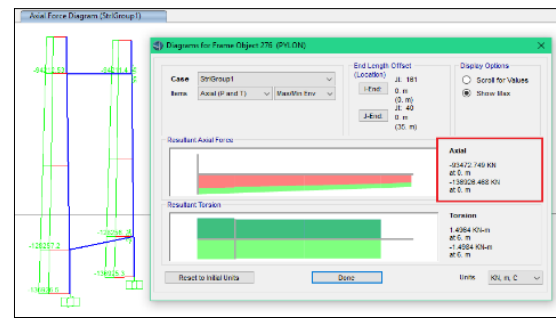

axial force diagram

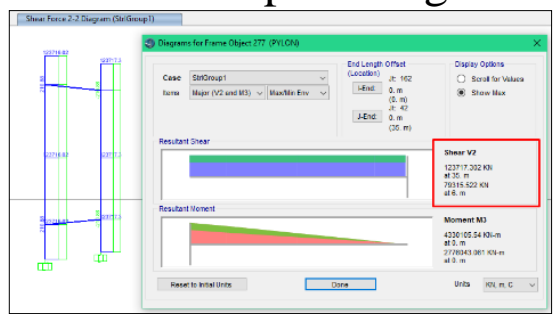

shear force diagram

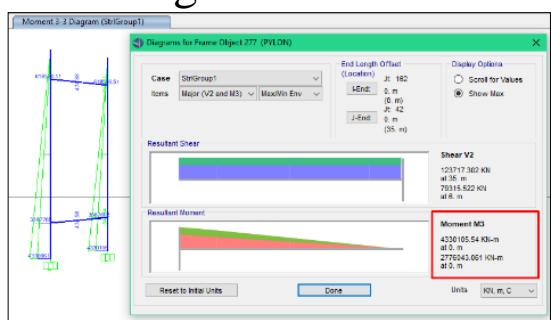

moment diagram

\section{Figure 16. The internal force diagrams for tower}

After the analysis is completed, the design process is started. For this, the design process can be performed by selecting the required regulations for steel and reinforced concrete sections by using the Advanced command in the program. As an example, the steel design for the 250-meter span steel-decked cable-stayed bridge system is given in Figure 17. AASHTO LRFD-2007 Design Code was used for the steel design. 
ROMANIAN JOURNAL

OF TRANSPORT INFRASTRUCTURE

Ali KÖKEN, Ahmed Ali Abdulqader FARHAD

Investigation of the effect of the deck material on the cost in cable-stayed bridges with different spans

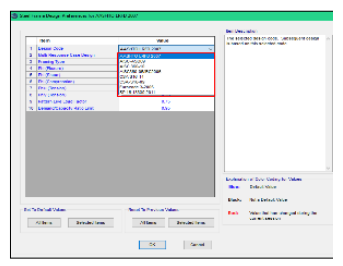

Steel design code

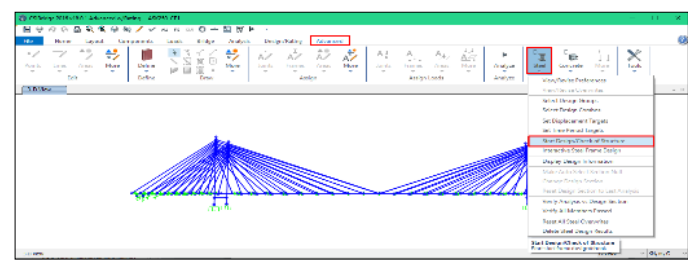

Start steel design of bridge

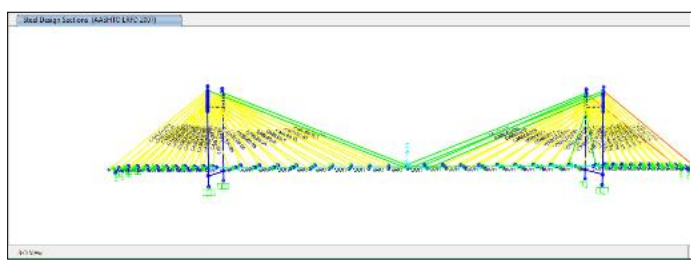

Steel design section

Figure 17. Pictures of the steel design

Similarly, the concrete design for the 250-meter span steel-decked cablestayed bridge system is given in Figure 18. AASHTO LRFD-2012 Design Code was used for the concrete design.

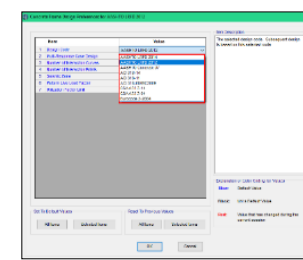

Concrete design code

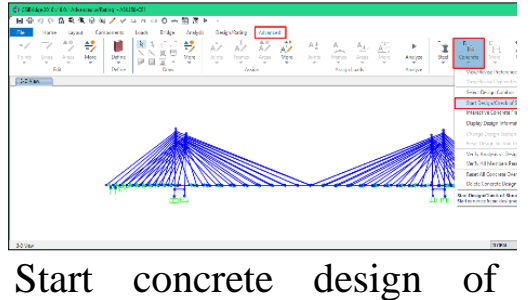

bridge

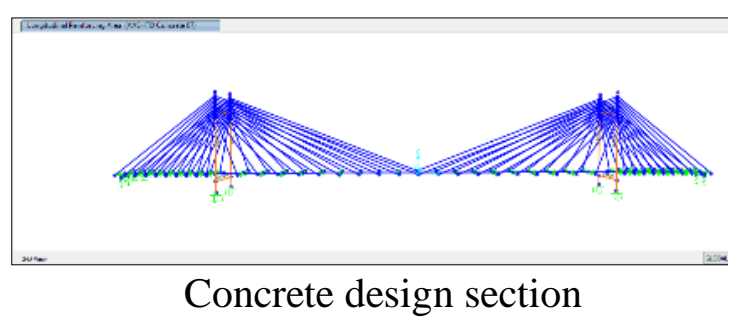

Concrete design section

Figure 18. Pictures of the concrete design

\section{RESULTS OBTAINED AND DISCUSSION}

In this study, the analysis of the cable-stayed bridges with a total of 12 different spans was carried out. Concrete and steel deck cable-stayed bridge types in 250, 500, 750, 1,000, 1,500 and 2,000-meter spans were modeled, analyzed and designed by using the CSI Bridge computer program. The results of sample pictures of the analysis and design are given below in Figures 19-21.

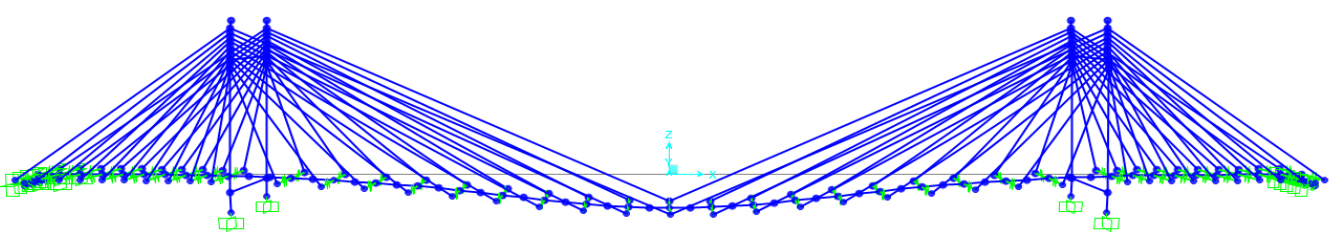

Figure 19. Displacement diagram obtained for a typical cable-stayed bridge system 
ROMANIAN JOURNAL

OF TRANSPORT INFRASTRUCTURE

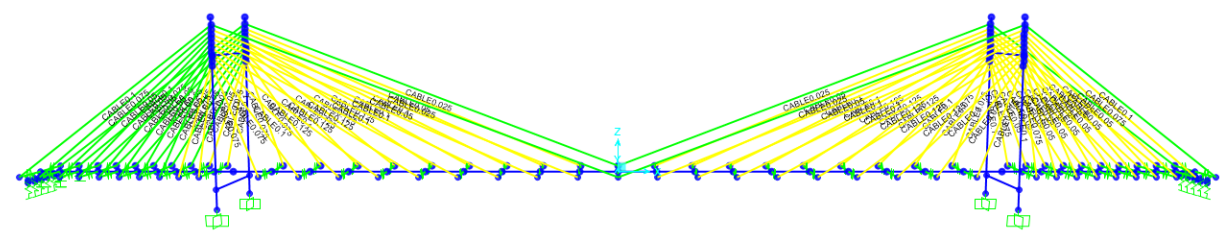

\section{Figure 20. Steel material design}

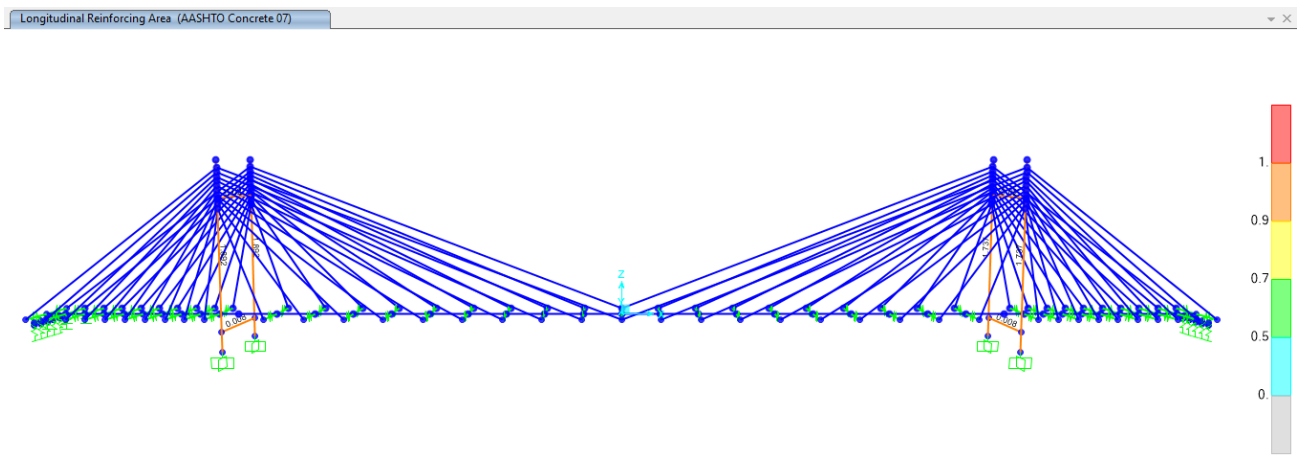

\section{Figure 21. Concrete material design}

At the end of the design implementation, weight and cost calculations of the bridges were made. Cost calculations were made using current prices and in US dollars. Material prices are given in Table 1.

Table 1. Material price list

\begin{tabular}{|l|l|}
\hline Elements & Unit Price \\
\hline Cable price & $1500 \$ /$ tons \\
\hline Concrete price & $40 \$ / \mathrm{m}^{3}$ \\
\hline Reinforcement/Steel price & $650 \$ /$ tons \\
\hline
\end{tabular}

\subsection{Results obtained for concrete desk cable-stayed bridges}

The results obtained for cable-stayed bridges with concrete deck are given in Tables 2-5. While the maximum internal forces obtained for the bridge towers 
ROMANIAN JOURNAL

OF TRANSPORT INFRASTRUCTURE

Ali KÖKEN, Ahmed Ali Abdulqader FARHAD

Investigation of the effect of the deck material on the cost in cable-stayed bridges with different spans

are given in Table 2, the length of the bridge and the dimensions of the tower are given in Table 3.

Table 2. Maximum internal forces obtained for bridge towers

\begin{tabular}{|c|c|c|c|}
\hline \multirow{2}{*}{ Bridge Type } & \multicolumn{3}{|c|}{ Maximum internal forces } \\
\cline { 2 - 4 } & $\begin{array}{c}\text { Axial force } \\
(\mathrm{KN})\end{array}$ & $\begin{array}{c}\text { Shear force } \\
(\mathrm{KN})\end{array}$ & $\begin{array}{c}\text { Moment } \\
(\mathrm{KN} . \mathrm{m})\end{array}$ \\
\hline ASK250-BE & 142.513 & 52.222 & 2.636 .131 \\
\hline ASK500-BE & 404.218 & 57.930 & 5.497 .486 \\
\hline ASK750-BE & 952.240 & 111.214 & 16.759 .686 \\
\hline ASK1000-BE & 1.724 .921 & 143.562 & 28.827 .326 \\
\hline ASK1500-BE & 5.220 .627 & 301.503 & 94.832 .522 \\
\hline ASK2000-BE & 12.015 .197 & 456.507 & 193.897 .314 \\
\hline
\end{tabular}

Table 3. The length of the bridge and the dimensions of the tower

\begin{tabular}{|c|c|c|c|c|c|c|}
\hline \multirow{2}{*}{ Bridge Type } & \multicolumn{3}{|c|}{$\begin{array}{c}\text { Tower dimensions } \\
(\mathrm{m})\end{array}$} \\
\cline { 2 - 7 } & \multicolumn{3}{|c|}{ Length of bridges } & Tower height & $\begin{array}{c}\text { Tower } \\
\text { cross } \\
\text { section }\end{array}$ \\
\cline { 2 - 7 } & $\begin{array}{c}\text { Middle } \\
\text { opening } \\
\mathrm{L}(\mathrm{m})\end{array}$ & $\begin{array}{c}\text { Side opening } \\
(\mathrm{m})\end{array}$ & $\begin{array}{c}\text { Total } \\
\text { length }(\mathrm{m})\end{array}$ & & $\mathrm{H}$ & $\mathrm{B}$ \\
\hline ASK250-BE & 250 & $62.5 * 2=125$ & 375 & $50+10=60$ & 8 & 4 \\
\hline ASK500-BE & 500 & $125 * 2=250$ & 750 & $100+20=120$ & 10.5 & 5.25 \\
\hline ASK750-BE & 750 & $187.5 * 2=375$ & 1125 & $150+30=180$ & 15.5 & 7.75 \\
\hline ASK1000-BE & 1000 & $250 * 2=500$ & 1500 & $200+40=240$ & 19 & 9.5 \\
\hline ASK1500-BE & 1500 & $375 * 2=750$ & 2250 & $300+60=360$ & 29 & 14.5 \\
\hline ASK2000-BE & 2000 & $500 * 2=1000$ & 3000 & $400+80=480$ & 39 & 19.5 \\
\hline
\end{tabular}

The amount of material for concrete deck cable-stayed bridges is given in table 4 and Material and bridge price for concrete deck cable-stayed bridges is shown in table 5 . 
Table 4. Amount of material for concrete deck cable-stayed bridges

\begin{tabular}{|c|c|c|c|c|c|c|c|c|c|c|}
\hline \multirow{3}{*}{ Bridge Type } & \multicolumn{10}{|c|}{ Material Weight (Ton) } \\
\hline & \multicolumn{5}{|c|}{ Concrete } & \multicolumn{4}{|c|}{ Reinforcement steel } & \multirow{2}{*}{$\begin{array}{c}\text { Cable } \\
\text { Steel } \\
\text { Cable }\end{array}$} \\
\hline & Tower & Beam & Deck & $\begin{array}{c}\text { Total } \\
\text { Concrete } \\
\text { (Ton) }\end{array}$ & $\begin{array}{c}\text { Total } \\
\text { Concrete } \\
\left(\mathrm{m}^{3}\right)\end{array}$ & Tower & Beam & Deck & $\begin{array}{l}\text { Total } \\
\text { Steel }\end{array}$ & \\
\hline ASK250-BE & 19.573 & 382 & 20.804 & 40.759 & 16.983 & 2.032 & 13 & 2.080 & 4.125 & 235 \\
\hline ASK500-BE & 67.434 & 841 & 41.608 & 109.883 & 45.785 & 6.198 & 30 & 4.161 & 10.388 & 1.292 \\
\hline ASK750-BE & 220.423 & 917 & 62.412 & 283.752 & 118.230 & 19.755 & 33 & 6.241 & 26.029 & 2.789 \\
\hline ASK1000-BE & 441.611 & 994 & 83.216 & 525.820 & 219.092 & 38.468 & 37 & 8.322 & 46.827 & 4.944 \\
\hline ASK1500-BE & 1.543 .191 & 1.950 & 124.823 & 1.669 .964 & 695.818 & 132.329 & 70 & 12.482 & 144.882 & 9.785 \\
\hline ASK2000-BE & 3.721 .273 & 2.210 & 166.431 & 3.889 .914 & 1.620 .797 & 299.021 & 83 & 16.643 & 315.747 & 16.271 \\
\hline
\end{tabular}

Table 5. Material and bridge price for concrete deck cable-stayed bridges

\begin{tabular}{|c|c|c|c|c|c|}
\hline \multirow{3}{*}{ Bridge Type } & \multicolumn{5}{|c|}{ Material Price $(\$)$} \\
\hline & $\begin{array}{c}\text { Total } \\
\text { Concrete } \\
\text { Price } \\
\end{array}$ & \begin{tabular}{|c|} 
Total \\
Reinforcement \\
Steel Price \\
\end{tabular} & $\begin{array}{c}\text { Cable } \\
\text { Steel Price }\end{array}$ & $\begin{array}{c}\text { Total Price } \\
(\$)\end{array}$ & $\begin{array}{l}\text { Unit } \\
\text { Price }\end{array}$ \\
\hline & $(\$)$ & $(\$)$ & $(\$)$ & & (\$/meter) \\
\hline ASK250-BE & 679.316 & 2.681 .302 & 352.617 & 3.713 .235 & 14.853 \\
\hline ASK500-BE & 1.831 .385 & 6.752 .182 & 1.937 .861 & 10.521 .429 & 21.043 \\
\hline ASK750-BE & 4.729 .203 & 16.919 .025 & 4.183 .070 & 25.831 .298 & 34.442 \\
\hline ASK1000-BE & 8.763 .669 & 30.437 .262 & 7.416 .111 & 46.617 .042 & 46.617 \\
\hline ASK1500-BE & 27.832 .726 & 94.173 .109 & 14.676 .809 & 136.682 .644 & 91.122 \\
\hline ASK2000-BE & 64.831 .893 & 205.235 .492 & 24.407 .136 & 294.474 .521 & 147.237 \\
\hline
\end{tabular}

\subsection{Results obtained for steel desk cable-stayed bridges}

The results obtained for steel deck cable-stayed bridges are given in Tables 6-9. While the maximum internal forces obtained for the bridge towers are given in Table 6, the length of the bridge and the dimensions of the tower are given in Table 7. 


\section{ROMANIAN JOURNAL \\ OF TRANSPORT INFRASTRUCTURE}

Ali KÖKEN, Ahmed Ali Abdulqader FARHAD

Investigation of the effect of the deck material on the cost in cable-stayed bridges with different spans

Table 6. Maximum internal forces obtained for bridge towers

\begin{tabular}{|c|c|c|c|}
\hline \multirow{2}{*}{ Bridge Type } & \multicolumn{3}{|c|}{ Maximum internal forces } \\
\cline { 2 - 4 } & Axial force $(\mathrm{KN})$ & & Axial force $(\mathrm{KN})$ \\
\hline ASK250-CE & 64.075 & 16.495 & 826.265 \\
\hline ASK500-CE & 221.832 & 31.196 & 3.156 .795 \\
\hline ASK750-CE & 482.297 & 37.669 & 5.584 .438 \\
\hline ASK1000-CE & 980.891 & 63.318 & 12.957 .916 \\
\hline ASK1500-CE & 3.761 .309 & 170.335 & 53.943 .238 \\
\hline ASK2000-CE & 10.405 .822 & 311.975 & 132.576 .438 \\
\hline
\end{tabular}

Table 7. The length of the bridge and the dimensions of the tower

\begin{tabular}{|c|c|c|c|c|c|c|}
\hline \multirow{3}{*}{ Bridge Type } & \multirow{2}{*}{\multicolumn{3}{|c|}{ Length of bridges }} & \multicolumn{3}{|c|}{$\begin{array}{l}\text { Tower dimensions } \\
\text { (m) }\end{array}$} \\
\hline & & & & \multirow[b]{2}{*}{ Tower height } & \multicolumn{2}{|c|}{$\begin{array}{c}\text { Tower cross } \\
\text { section }\end{array}$} \\
\hline & $\begin{array}{l}\text { Middle } \\
\text { opening } \\
\mathrm{L}(\mathrm{m})\end{array}$ & $\begin{array}{l}\text { Side opening } \\
\text { (m) }\end{array}$ & $\begin{array}{l}\text { Total length } \\
\text { (m) }\end{array}$ & & $\mathrm{H}$ & B \\
\hline ASK250-CE & 250 & $62.5 * 2=125$ & 375 & $50+10=60$ & 5.5 & 2.75 \\
\hline ASK500-CE & 500 & $125 * 2=250$ & 750 & $100+20=120$ & 9 & 4.5 \\
\hline ASK750-CE & 750 & $187.5 * 2=375$ & 1125 & $150+30=180$ & 11.5 & 5.75 \\
\hline ASK1000-CE & 1000 & $250 * 2=500$ & 1500 & $200+40=240$ & 15 & 7.5 \\
\hline ASK1500-CE & 1500 & $375 * 2=750$ & 2250 & $300+60=360$ & 25 & 12.5 \\
\hline ASK2000-CE & 2000 & $500 * 2=1000$ & 3000 & $400+80=480$ & 36.5 & 18.25 \\
\hline
\end{tabular}

The amount of material for steel deck cable-stayed bridges is shown in table 8 and Material and bridge price for steel deck cable-stayed bridges is given in table 9 .

Table 8. Amount of material for steel deck cable-stayed bridges

\begin{tabular}{|c|c|c|c|c|c|c|c|c|c|}
\hline \multirow{3}{*}{ Bridge Type } & \multicolumn{9}{|c|}{ Material Weight (Ton) } \\
\hline & \multicolumn{4}{|c|}{ Concrete } & \multicolumn{3}{|c|}{ Reinforcement steel } & \multirow{2}{*}{$\begin{array}{c}\begin{array}{c}\text { Profile } \\
\text { steel }\end{array} \\
\text { Profile } \\
\text { Steel } \\
\text { (Ton) }\end{array}$} & \multirow{2}{*}{$\begin{array}{l}\text { Cable } \\
\text { Cable } \\
\text { (Ton) }\end{array}$} \\
\hline & $\begin{array}{l}\text { Tower } \\
\text { (Ton) }\end{array}$ & $\begin{array}{l}\text { Beam } \\
\text { (Ton) }\end{array}$ & $\begin{array}{c}\text { Total } \\
\text { concrete } \\
\text { (Ton) }\end{array}$ & $\begin{array}{c}\text { Total } \\
\text { concrete } \\
\left(\mathrm{m}^{3}\right)\end{array}$ & $\begin{array}{l}\text { Tower } \\
\text { (Ton) }\end{array}$ & $\begin{array}{l}\text { Beam } \\
\text { (Ton) }\end{array}$ & $\begin{array}{l}\text { Total } \\
\text { Steel } \\
\text { (Ton) } \\
\end{array}$ & & \\
\hline ASK250-CE & 9.251 & 248 & 9.500 & 3.958 & 956 & 9 & 965 & 5.260 & 115 \\
\hline ASK500-CE & 49.544 & 421 & 49.964 & 20.818 & 4.129 & 16 & 4.146 & 10.520 & 491 \\
\hline ASK750-CE & 121.336 & 459 & 121.795 & 50.748 & 9.432 & 19 & 9.451 & 15.779 & 1.132 \\
\hline ASK1000-CE & 275.242 & 994 & 276.236 & 115.098 & 24.638 & 37 & 24.675 & 21.039 & 1.854 \\
\hline ASK1500-CE & 1.146 .842 & 1.147 & 1.147 .989 & 478.329 & 94.031 & 45 & 94.076 & 52.893 & 4.992 \\
\hline ASK2000-CE & 3.259 .478 & 2.210 & 3.261 .687 & 1.359 .036 & 219.778 & 83 & 219.861 & 102.365 & 10.819 \\
\hline
\end{tabular}


ROMANIAN JOURNAL

OF TRANSPORT INFRASTRUCTURE

Ali KÖKEN, Ahmed Ali Abdulqader FARHAD

Investigation of the effect of the deck material on the cost in cable-stayed bridges with different spans

Table 9. Material and price of bridges for steel deck cable-stayed bridges

\begin{tabular}{|c|c|c|c|c|c|c|}
\hline \multirow{2}{*}{ Bridge Type } & \multicolumn{7}{|c|}{ Material Price $(\$)$} \\
\cline { 2 - 7 } & $\begin{array}{c}\text { Total } \\
\text { Concrete } \\
\text { Price }\end{array}$ & $\begin{array}{c}\text { Total } \\
\text { Reinforcement } \\
\text { Steel Price }\end{array}$ & $\begin{array}{c}\text { Cable } \\
\text { Steel Price }\end{array}$ & $\begin{array}{c}\text { Steel } \\
\text { Profile } \\
\text { Price }\end{array}$ & Total Price & Unit Price \\
\cline { 2 - 7 } & $(\$)$ & $(\$)$ & $(\$)$ & $(\$)$ & $(\$)$ & $(\$ /$ metre $)$ \\
\hline ASK250-CE & 158.328 & 627.019 & 172.457 & 3.418 .853 & 4.376 .657 & 17.507 \\
\hline ASK500-CE & 832.735 & 2.694 .579 & 736.949 & 6.837 .706 & 11.101 .969 & 22.204 \\
\hline ASK750-CE & 2.029 .910 & 6.143 .170 & 1.698 .332 & 10.256 .559 & 20.127 .971 & 26.837 \\
\hline ASK1000-CE & 4.603 .933 & 16.038 .870 & 2.780 .935 & 13.675 .413 & 37.099 .150 & 37.099 \\
\hline ASK1500-CE & 19.133 .147 & 61.149 .554 & 7.488 .625 & 34.380 .300 & 122.151 .625 & 81.434 \\
\hline ASK2000-CE & 54.361 .456 & 142.909 .928 & 16.228 .479 & 66.537 .503 & 280.037 .366 & 140.019 \\
\hline
\end{tabular}

Graphic representations of the obtained results are given in Figure 22-25.

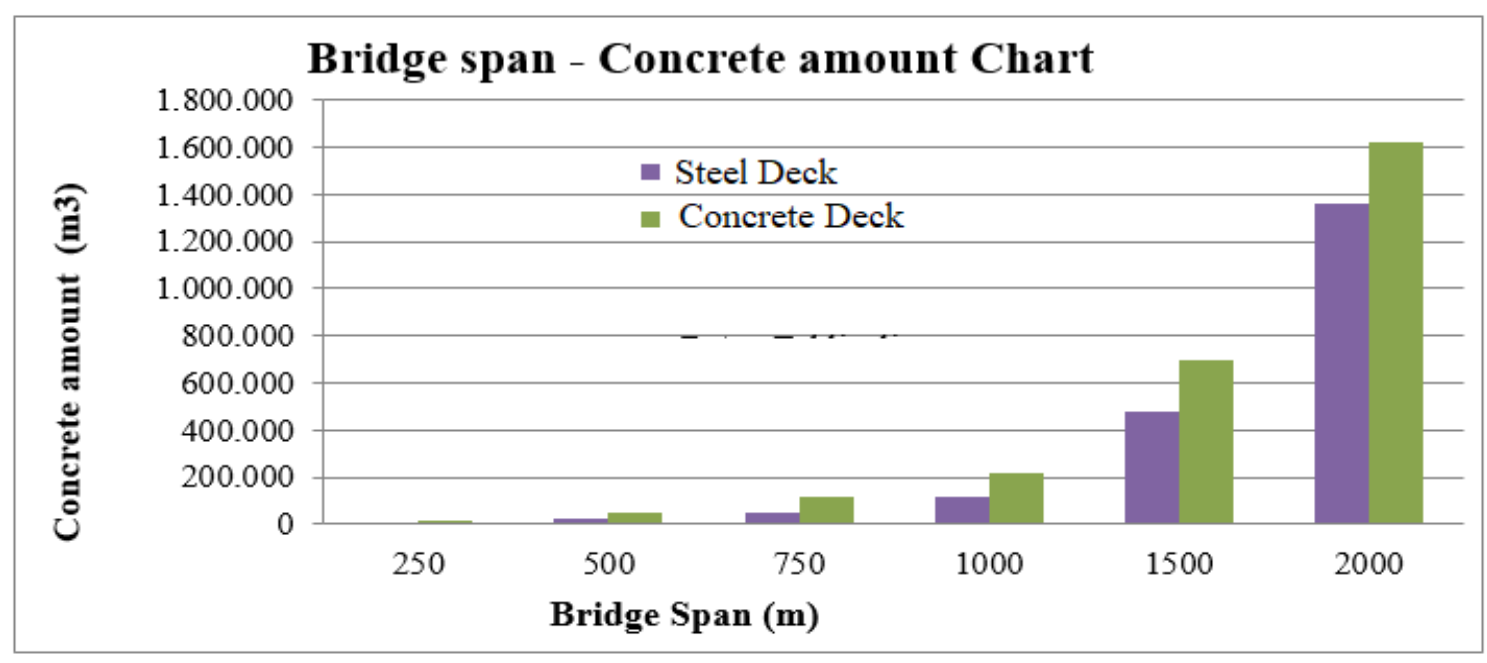

Figure 22. Bridge span - Concrete amount chart

As can be seen in Figure 22, the amount of concrete in concrete deck cablestayed bridges is higher than the systems with steel decks. For the 250-meter span, the concrete amount for the bridge with a concrete deck is $16,983 \mathrm{~m} 3$, while it is $3,958 \mathrm{~m} 3$ for the steel deck system. It is necessary to use $329 \%$ more concrete in the concrete deck system compared to the steel deck system. The amount of concrete for the bridge with concrete deck for a span of 2,000 meters is 1.620 .797 $\mathrm{m} 3$, while it is $1.359 .036 \mathrm{~m} 3$ in the steel deck system. $19 \%$ more concrete should be used in the concrete deck system compared to the steel deck system. As the span of the bridge increases, the difference between the amount of concrete used for the concrete and steel deck cable-stayed bridge systems decreases considerably. 
ROMANIAN JOURNAL

OF TRANSPORT INFRASTRUCTURE

Ali KÖKEN, Ahmed Ali Abdulqader FARHAD

Investigation of the effect of the deck material on the cost in cable-stayed bridges with different spans

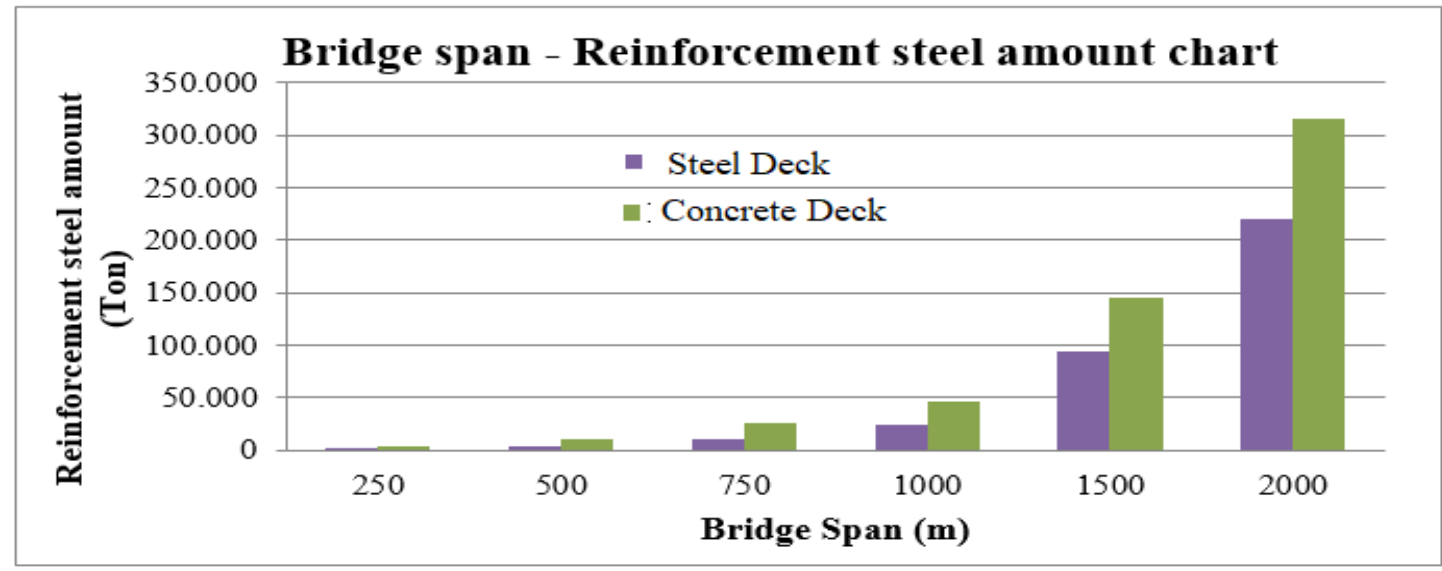

Figure 23. Bridge span - reinforcement steel amount chart

As can be seen in Figure 23, the amount of reinforcement steel in concrete deck cable-stayed bridges is higher than that of systems with steel decks. For 250meter span, the amount of reinforcement steel in the bridge with a concrete deck is 4.125 tons, while it is 965 tons in the steel deck system. It is necessary to use $327 \%$ more reinforcement steel in the concrete deck system compared to the steel deck system. The amount of reinforcement steel for the bridge with concrete deck for a span of 2,000 meters is 315.747 tons, while it is 219.861 tons for the steel deck system. In the concrete deck system, $43 \%$ more reinforcement steel must be used compared to the steel deck system. As the span of the bridge increases, the difference in the amount of reinforcement steel used for the concrete and steel deck cable-stayed bridge systems decreases considerably.

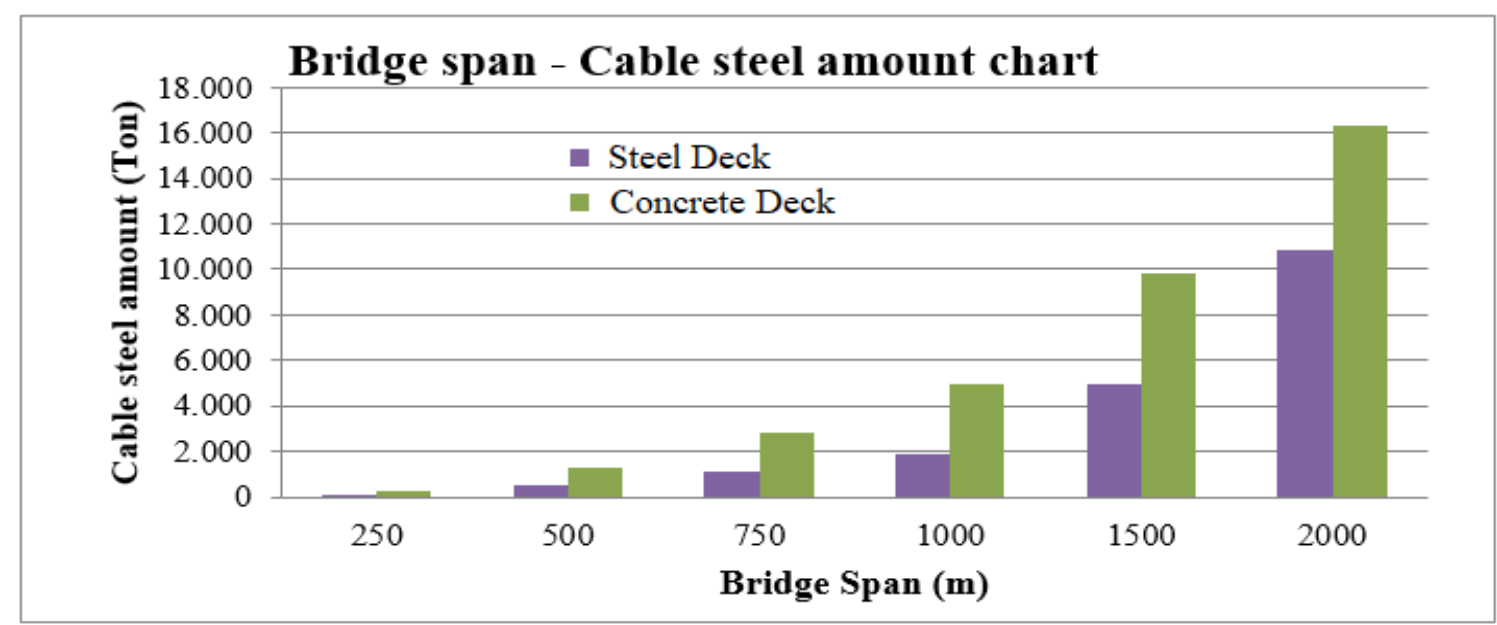

Figure 24. Bridge span - cable steel amount chart 
As can be seen in Figure 24, the amount of cable steel in concrete deck cable-stayed bridges is higher than that of systems with steel decks. For 250-meter span, the amount of cable steel in the bridge with a concrete deck is 235 tons, while it is 115 tons in the steel deck system. In the concrete deck system, 104\% more cable steel must be used compared to the steel deck system. For a 2,000meter span, the amount of cable steel in the bridge with a concrete deck is 16,271 tons, while it is 10.819 tons in the steel deck system. In the concrete deck system, $50 \%$ more cable steel must be used compared to the steel deck system. As the span of the bridge increases, the difference in the amount of cable steel used for the concrete and steel deck cable-stayed bridge systems decreases considerably.

Figure 25 shows the total material cost graph of the cable-stayed bridge systems with steel deck and concrete deck at different spans.

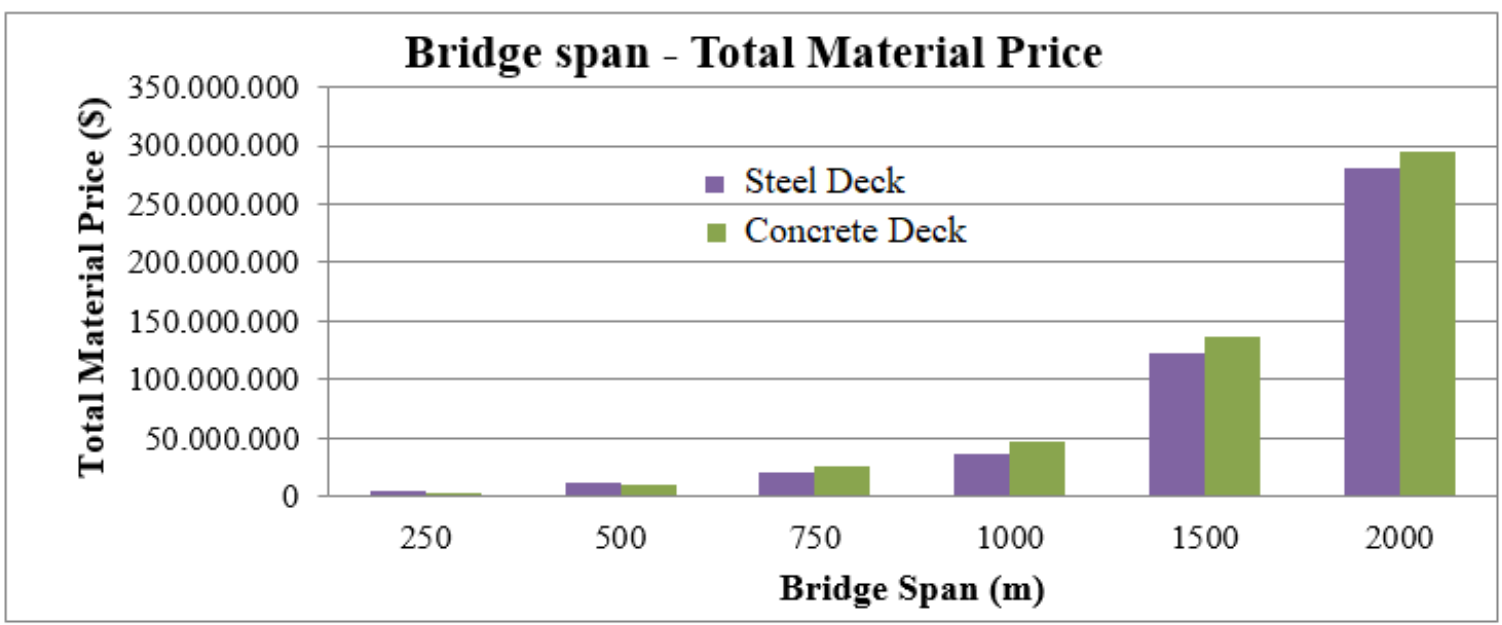

Figure 25. Bridge span - Total material price

\section{CONCLUSIONS}

Determining which construction system and material to use in the construction of cable-stayed bridges gives more appropriate and economical results is necessary and important for bridge construction. For this purpose, necessary analyses and designs were carried out to conduct the economic research of the cable-stayed bridge systems with different features. At the end of the analyses and cost calculations, the following results were reached. 
- For the 250-meter span, the total cost of the concrete deck bridge is $\$ 3,713,235$, while it is $\$ 4,376,657$ for the steel deck bridge system. The cost of the steel deck system is $18 \%$ more than the concrete deck system.

- The total cost of the bridge for the concrete deck bridge for the 750-meter span is $\$ 25,831,298$, while it is $\$ 20,127,971$ for the steel deck system. The cost of the concrete deck system was found to be $28 \%$ higher than the steel deck system.

- The total cost of the bridge for the concrete deck bridge for the 2,000meter span is $\$ 294,474,521$, while it is $\$ 280,037,366$ for the steel deck system. The cost of the concrete deck system is $5 \%$ higher than the steel deck system.

- When the cost of the concrete and steel deck cable-stayed bridge systems is examined, while the concrete deck systems up to the 500-meter span give more economical results, steel deck systems give more economical results after the 750-meters span.

\section{REFERENCES}

[1] Akca, H. A., 2009, Çelik Kemer Köprülerin Sonlu Elemanlar Programı ile Modellenmesi, Yüksek Lisans Tezi, Gazi Üniversitesi Fen Bilimleri Enstitüsü, Ankara.

[2] Boduroğlu, M. K., 2007, Kablolu Köprülerin Zaman Tanım Alanında Doğrusal Olmayan Analiz Yöntemi ile Deprem Performansının Belirlenmesi Üzerine Sayısal Bir İnceleme, Yüksek Lisans Tezi, Gazi Üniversitesi Fen Bilimleri Enstitüsü, Ankara.

[3] Çetindemir, O., 2011, Çelik Tabliyeli Eğik Kablo Askılı Köprülerin Deprem Performanslarının İncelenmesi, Yüksek Lisans Tezi, Gebze Yüksek Teknoloji Üniversitesi Mühendislik ve Fen Bilimleri Enstitüsü, Gebze.

[4] Eğriboyun, O., 2008, Farklı Kablo Düzenlemelerine Sahip Çift Tabliyeli Kablolu Köprülerin İncelenmesi, Yüksek Lisans Tezi, Karadeniz Teknik Üniversitesi Fen Bilimleri Enstitüsü, Trabzon.

[5] Cengiz, A., 2009, Büyük Açıklıklı Kablolu Köprülerde Trafik Yüklerinin Meydana Getirdiği Dinamik Etkilerin İncelenmesi, Yüksek Lisans Tezi, Gazi Üniversitesi Fen Bilimleri Enstitüsü, Ankara.

[6] Cengizoğlu, H., 2006, Asma Bir Köprünün Orjinal Tasarım Dayanımının Kopan Bağlantı Plağından Sonraki Durumu ile Kıyaslanması, Yüksek Lisans Tezi, İstanbul Üniversitesi Fen Bilimleri Enstitüsü, İstanbul. 


\section{ROMANIAN JOURNAL \\ OF TRANSPORT INFRASTRUCTURE}

Ali KÖKEN, Ahmed Ali Abdulqader FARHAD

Investigation of the effect of the deck material on the cost in cable-stayed bridges with different spans

[7] Laçin, E. E., 2017, Gergin Eğik Askılı Köprülerin Tasarım Esasları, Mevcut Bir Gergin Eğik Ask1lı Köprünün Sayısal Analizi Ve Değerlendirmesi Yüksek Lisans Tezi, İstanbul Teknik Üniversitesi, Fen Bilimleri Enstitüsü, İstanbul.

[8] Gimsing NJ, Georgakis CT. Cable supported bridges: concept and design. 3rd ed. Hoboken, NJ: Wiley; 2012.

[9] Svensson H. Cable-stayed bridges: 40 years of experience worldwide. 1st ed. Berlin: Ernst, Wiley-Blackwell; 2012.

[10] Walther R. Cable stayed bridges. 2nd ed. London: Telford; 1999.

[11] Podolny W, Scalzi JB. Construction and design of cable-stayed bridges. 2nd ed. New York: Wiley; 1986.

[12] Troitsky MS. Cable-stayed bridges: theory and design. London: Crosby Lockwood Staples; 1977.

[13] Günaydın, M., 2011, Asma Köprülerin Yapısal Davranışının Yapım Aşamaları Dikkate Alınarak Belirlenmesi, Yüksek Lisans Tezi, Karadeniz Teknik Üniversitesi Fen Bilimleri Enstitüsü, Trabzon..

[14] Farhad A. A. A., 2018, Eğik Kablo Askılı ve Asma Köprü Tiplerinin Ekonomik Karşılaştırılması, S.Ü. Fen Bilimleri Enstitüsü Yüksek Lisans Tezi, Konya.

[15] AASHTO, 2012, AASHTO LRFD 2012 BridgeDesignSpecifications 6th Edition. ABD, American Association of State Highway and Transportation Officials..

[16] Atabey, N. A., 2011, Lifli Polimer Kompozit Asma Köprülerin Statik ve Dinamik Analizi, Yüksek Lisans Tezi, Karadeniz Teknik Üniversitesi Fen Bilimleri Enstitüsü, Trabzon.

[17] Atmaca, B., 2012, Kablolu Köprülerin Yapım Aşamalarına Göre Analizi, Yüksek Lisans Tezi, Karadeniz Teknik Üniversitesi Fen Bilimleri Enstitüsü, Trabzon.

[18] Uluğ, N. İ., 2008, Öngerilmeli Bir Köprü Tasarımı Ve Performans Değerlendirilmesi, Fen Bilimleri Enstitüsü, İstanbul. 